\title{
Biochemical status of turkeys when fed with a complex nano- additive
}

\author{
Irina Vorotnikova, Schavket Zyalalov, Svetlana Dezhatkina*, and Nikolay Lyubin \\ Ulyanovsk State Agrarian University named after P.A. Stolypin, 432017 Ulyanovsk, Russia
}

\begin{abstract}
The positive effect of a complex additive based on nanozeolite and soy okara on the biochemical status and anabolic processes in turkeys was established. Tests were carried out in the Ulyanovsk region at the facilities of a farm for young turkeys of the breed "Hybrid Grade Maker". We formed two groups using the method of analogs: control and experimental groups of 10 birds each. The supplement was added to the diet in the amount of $100 \mathrm{~g} / \mathrm{head} / \mathrm{day}$. The subject of the study was the blood of birds, which was taken from the axillary vein before morning feeding. Under the influence of the supplement, an increase in anabolic processes in the body of turkeys was revealed. An increase in albumin by $7.38 \% \mathrm{p}<0.05$, creatinine by $19.32 \% \mathrm{p}<0.05$ with a decrease in nitrogenous products was found. It is confirmed by an increase in the average daily weight gains of turkeys by $13-18.3 \%$. There was a decrease in the activity of AST aminotransferases. Decreased of the products nitrous metabolism is revealed: urea concentration per uric acid. Improved feather cover of birds and reduced cannibalism among birds.
\end{abstract}

\section{Introduction}

Widespread environmental pollution has contributed to the accumulation of radionuclides, heavy metals, and other harmful and toxic substances in the soil, water, and feed. This negatively affects the quality of feed, the balance of nutrients and minerals in the diets of birds and animals, causes metabolic disorders and reduced immunity and productivity $[1,13,14]$.

For prevention and treatment, complex medications of multi-faceted action are needed, providing correction of all types of metabolism. One of the priority directions is the use of metal nanoparticles-trace elements as feed additives in livestock and poultry [2]. Since nanocrystalline microelements have a higher coefficient of assimilation, approaching $100 \%$, compared to elements of normal size, which have it equal to about 30 .

In Russia, since 1997, turkey breeding industry has been actively growing. It is known that modern turkey crosses have a genetically determined high growth rate, but are sensitive to even minor fluctuations in the diet. Especially these birds are susceptible to a deficiency of amino acids, protein, mineral elements and vitamins, which contributes to a decrease in their productivity and the development of pathological processes and diseases. Therefore, one of the main tasks for actualizing the genetic potential of high productivity of turkeys is their balanced nutrition [3].

In recent years, non-traditional natural additives based on natural minerals of non-metallic origin and food waste have become widely used in poultry farming.
Their use is due to the relatively low price and positive impact on the level of metabolism, increased resistance of the body to adverse environmental factors and productivity of birds [4].

Modern introduction of nanotechnologies into production allows changing and improving the properties of natural minerals, removing unnecessary impurities and substances in them, and enriching minerals with nutrients and biologically active substances. All this makes it possible to produce new natural and highly effective feed additives $[5,6]$.

\section{Materials and methods}

The aim of the work is to study the effect of complex nanoparticles based on nanozeolite (deposits of the Ulyanovsk region) and soy okara (waste from soy production) on the biochemical parameters of turkeys.

As the research material, we used a complex additive based on modified (high-tech processed) natural zeolite from the Yushanskoye field, Ulyanovsk region, and a product of soy bean processing (soy okara).

It is important to note that zeolites are defined as three-dimensional crystal structures with uniform pores of molecular size. Zeolites have a system of cavities and channels, and contain up to 40 mineral elements. Cations and water molecules are weakly bound to the framework and can be partially or completely removed by ion exchange and dehydration. It is proved that zeolite is multifunctional and has important properties: sorption, molecular sieves, ion exchange and catalytic. The level of exchange calcium in the rock of the volcano-

\footnotetext{
Corresponding author: dsw1710@yandex.ru
} 
sedimentary type of the Ulyanovsk region Deposit reaches up to $88 \%$, and that of silicon is up to $36 \%$ [7, 11]. Due to this, this mineral is a popular material for creating natural mineral and complex highly effective additives for animals and birds [8,9]. The use of various degrees of mechanical, thermal and ultrasonic activation of quarry zeolite allowed us to develop nanozeolite, whose properties are several times higher.

Another equally valuable component of the additive was the departure from the production of soy milk obtained on filter presses-soy okara. It notes the high quality of protein, the protein efficiency coefficient is estimated at 2.71, the unique amino acid composition, up to 16 amino acids, dietary fiber from $35 \ldots 58 \%$, easily digestible bivalent iron, as well as mineral elements and B vitamins [10, 12].

To achieve this goal, we conducted production tests at the farm "Sankeev S. A." in the Ulyanovsk region. The object of research was birds-young turkeys of the breed "Hybrid Grade Maker" 40..45-day-old. We formed two groups (1st control and 2nd experiment) for a physiological experiment using analogs of 10 birds each. All birds received the same diet. A complex Supplement at the rate of $100 \mathrm{~g} / \mathrm{head} / \mathrm{day}$ was mixed with feed and once a day was introduced into the diet of turkeys of the experimental group. The control group did not receive the supplement.

The chemical composition of the additive is shown in Table 1.

Table 1. The chemical composition of the additive on the basis of nanozeolite and soy okara

\begin{tabular}{|l|c|}
\hline \multicolumn{1}{|c|}{ Indicator, units. } & Quantity \\
\hline Dry substance, $\mathrm{kg}$ & 0.030 \\
\hline Crude protein, $\mathrm{g}$ & 10.70 \\
\hline Raw fat, $\mathrm{g}$ & 0.22 \\
\hline Digestible protein, $\mathrm{g}$ & 9.10 \\
\hline Lysine, $\mathrm{g}$ & 2.52 \\
\hline Methionine + cysteine, $\mathrm{g}$ & 1.00 \\
\hline Raw fiber, $\mathrm{g}$ & 2.28 \\
\hline Nitrogen-free extractives, $\mathrm{g}$ & 14.50 \\
\hline Calcium, g & 9.94 \\
\hline Phosphorus, g & 2.14 \\
\hline Magnesium, $\mathrm{g}$ & 8.66 \\
\hline Potassium, g & 9.87 \\
\hline Iron, mg & 420.00 \\
\hline Copper, mg & 5.56 \\
\hline Zinc, mg & 28.89 \\
\hline Manganese, mg & 62.78 \\
\hline Cobalt, mg & 1.19 \\
\hline Thiamine, $\mathrm{mg}$ & 0.35 \\
\hline Riboflavin, mg & 0.11 \\
\hline Pantothenic acid, mg & 0.94 \\
\hline Choline, g & 0.11 \\
\hline Nicotinic acid, mg & 6.00 \\
\hline
\end{tabular}

The subject of the study was the blood of birds, which was taken from the axillary vein before morning feeding. Biochemical parameters were determined using modern methods and devices: hematological analyzer "PCE-90Vet", biochemical analyzer" StatFax 1904
Plus", analyzer" AKBA-01-BIOM", spectrophotometer "Perkin Elmer".

\section{Results and Discussion}

The obtained data were processed using the Statistika software package, taking into account the Student's confidence criterion. The live weight of birds was determined by control weighing.

Based on a hematological study, it was found that the intake of the tested supplement into the body of turkeys of the 2nd group has a positive effect on their blood composition. A clear trend was found to increase the content of red blood cells by $7.39 \%$ and respiratory blood pigment - hemoglobin by $5.72 \%$, as well as the total number of white blood cells by $3.6 \%$, of which the most increased the number of immune response cells lymphocytes by $13.47 \%$ compared to the indicators in the 1 st-control group.

In the course of the experiment, we found that the intake of complex nanoparticles in the body of turkeys has a positive effect on the physiological and biochemical status of their body and metabolism. No deviations were detected, all biochemical parameters were within the physiological norm and are presented in Table 2.

Table 2. Biochemical parameters of blood of turkeys when feeding nanoparticles

\begin{tabular}{|l|l|l|}
\hline \multicolumn{1}{|c|}{ Indicator, units } & \multicolumn{1}{|c|}{$\begin{array}{c}\text { 1 group } \\
\text { control }\end{array}$} & \multicolumn{1}{c|}{$\begin{array}{c}\text { 2 group } \\
\text { experiment }\end{array}$} \\
\hline Total protein, g /l & $42.04 \pm 1.27$ & $44.89 \pm 1.17$ \\
\hline Albumins, \% & $31.40 \pm 0.57$ & $33.72 \pm 0.84 *$ \\
\hline$\alpha$ - globulins, \% & $16.13 \pm 0.27$ & $17.63 \pm 0.65$ \\
\hline$\beta$ - globulins, \% & $9.34 \pm 0.16$ & $9.95 \pm 0.18$ \\
\hline$\gamma$-globulins, \% & $29.06 \pm 0.67$ & $30.11 \pm 0.58$ \\
\hline A/G coefficient & $0.57 \pm 0.02$ & $0.58 \pm 0.01$ \\
\hline Urea, mmol/l & $0.49 \pm 0.01$ & $0.44 \pm 0.14 *$ \\
\hline Uric acid, mmol/l & $0.25 \pm 0.008$ & $0.22 \pm 0.004 *$ \\
\hline Creatinine, mkmol/1 & $77.44 \pm 3.52$ & $92.40 \pm 5.28^{*}$ \\
\hline AST, nkat/l & $721.83 \pm 12.31$ & $689.27 \pm 10.93$ \\
\hline ALT, nkat/l & $614.25 \pm 8.96$ & $635.94 \pm 14.98$ \\
\hline Glucose, $\mathrm{mmol} / \mathrm{l}$ & $7.48 \pm 0.28$ & $7.95 \pm 0.32$ \\
\hline Cholesterol, $\mathrm{mmol} / 1$ & $3.49 \pm 0.10$ & $3.28 \pm 0.08$ \\
\hline
\end{tabular}

Note: * $-(\mathrm{p}<0.05)$ compared to the control

Considering blood as a universal and labile system, it is important to emphasize that blood proteins are an important part and characterize the intensity of metabolism in the body.

According to research results, the introduction of nanozeolite in the diet of young turkeys in combination with soy Okara increases the intensity of protein metabolism, increasing the synthesis of new tissue proteins.

This is indicated by an increase in the total protein content in the blood serum of turkeys by $6.78 \%$, an increase in albumins by $7.38 \%(\mathrm{p}<0.05)$ (fig. 1$)$.

A tendency to increase the fractions: $\alpha$-globulins by $9.29 \%, \beta$-globulins by $6.53 \%$ and $\gamma$-globulins by $3.6 \%$, an increase in the normal albumin-globulin coefficient 
by $1.75 \%$. All indicators are shown in comparison with the control.

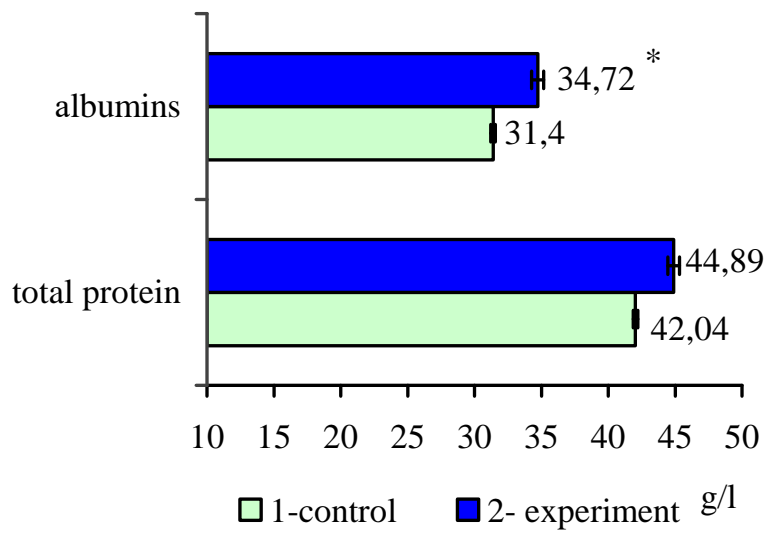

Fig. 1. The content of total protein and albumin in the blood of turkeys when using nanoparticles.

Note: $*$ - $(\mathrm{p}<0.05)$ compared to the control

The key enzymes of protein metabolism are considered to be aminotransferases, which as catalysts influence protein synthesis in the body. Increased reactions of amino acid transamination and increased aerobic glycolysis are indicated by data on the activity of enzyme systems.

Thus, the level of activity of aminotransferases, in particular ALT under the influence of nano-additives in the body of group 2 turkeys increased by $2.75 \%$ and amounted to $635.94 \pm 14.98 \mathrm{ncat} / \mathrm{l}$, at the same time, there was a decrease in the norms of AST activity by $5.51 \%$ and amounted to $689.27 \pm 10.93$ ncat $/ 1$.

The revealed pattern indicates activation of the synthesis of amino acids along the catabolic pathway, which allows you to economically consume amino acids. Consequently, amino acids that are not involved in protein synthesis are involved in the processes of catabolism (valine, leucine, isoleucine), while reducing urea formation, oxidation and the use of amino acids in the processes of gluconeogenesis.

This is confirmed by the data on the dynamics of nitrogen exchange products (fig. 2).

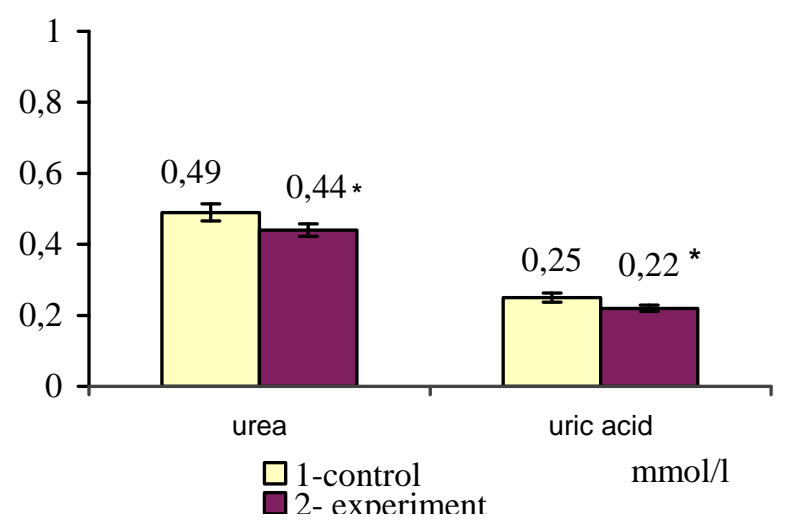

Fig. 2. The content of nitrogenous exchange products in the blood of turkeys when using nanoparticles. Note: * $(\mathrm{p}<0.05)$ compared to the control

The concentration of urea in the blood of birds of the experimental group, within the norm, decreased by 10.88 $\%$ and amounted to $0.44 \pm 0.14 \quad(\mathrm{p}<0.05)$, against $0.49 \pm 0.01 \mathrm{mmol} / \mathrm{l}$ in the control.
Uric acid levels decreased by $9.38 \%(\mathrm{p}<0.05)$, respectively. On the contrary, the creatinine content in the blood of group 2 turkeys when feeding nanoparticles increased by $19.32 \%$ and amounted to $92.40 \pm 5.28$ $(\mathrm{p}<0.05)$ against $77.44 \pm 3.52 \mathrm{mmol} / \mathrm{l}$ in the group of analogues. Thus, supplementing the diet of turkeys of nanozeolite and soy okara increases the intensity of anabolic processes in their body.

A decrease in the activity of the alkaline phosphatase enzyme by $4.7 \%$ was found in group 2 birds, which indicates a decrease in the load on their liver.

It is known that glucose is the main source of energy and has important clinical significance in determining the physiological state of the body. For example, the amount of glucose in the blood falls during fasting and liver failure and increases in a stressful situation. During the experiment, the blood glucose level of group 2 turkeys was within the physiological norm and amounted to $7.95 \pm 0.32 \mathrm{mmol} / \mathrm{l}$, which was higher than in group 1 by $6.28 \%$.

At the same time, a decrease in the concentration of cholesterol by $6.02 \%$ in the blood of birds of the experimental group, where this indicator was $3.28 \pm 0.08$ $\mathrm{mmol} / \mathrm{l}$, compared to $3.49 \pm 0.10 \mathrm{mmol} / \mathrm{l}$ in the group of analogues.

The use of additives in the feeding of turkeys helped to improve their plumage.

In the control group of birds, due to the lack of mineral elements and amino acids in their diet, there was a loss of feathers and rare plumage, splitting (cannibalism). This is evidence of a mineral deficiency in their body (fig. 3).

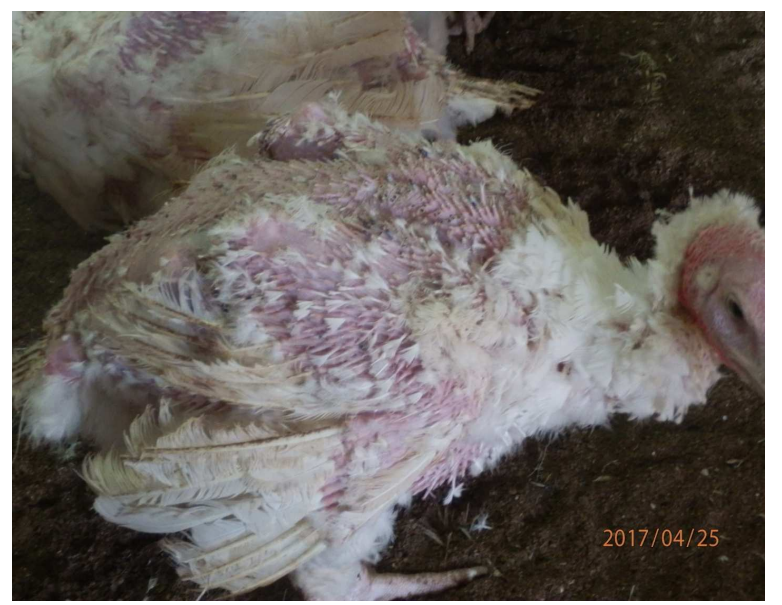

Fig. 3. Feathers of control group turkeys

Feeding a zeolite-based supplement rich in mineral elements, vitamins, protein, amino acids (including sulfur-containing ones) and carbohydrates, on the contrary, improved pen formation and eliminated the disease-splitting (fig. 4).

Positive dynamics in blood also affected the parameters of productivity of birds (fig. 5).

An increase in the average daily live weight gain of turkeys by $13-18.3 \%$ compared to the control was found. 
Consequently, feeding birds with a diet enriched with a complex additive of modified zeolite and soy okara had a positive effect on the intensity of their growth.

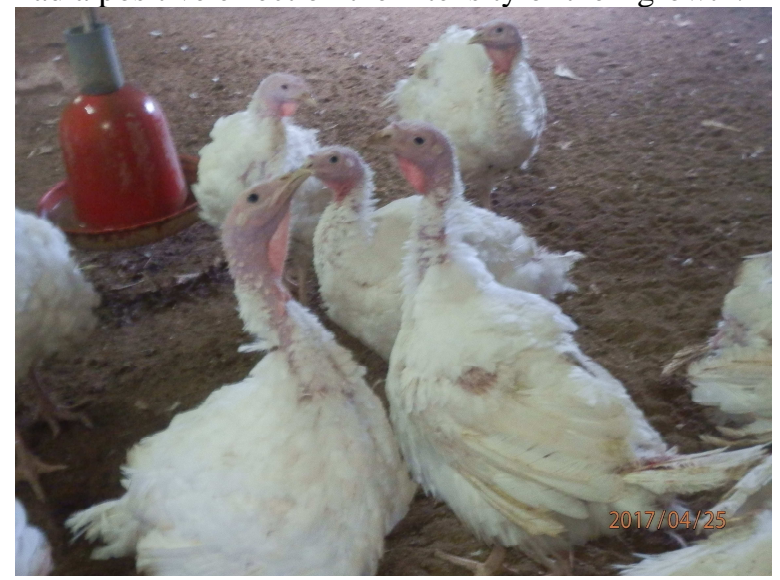

Fig. 4. Feathers of birds of the experimental group

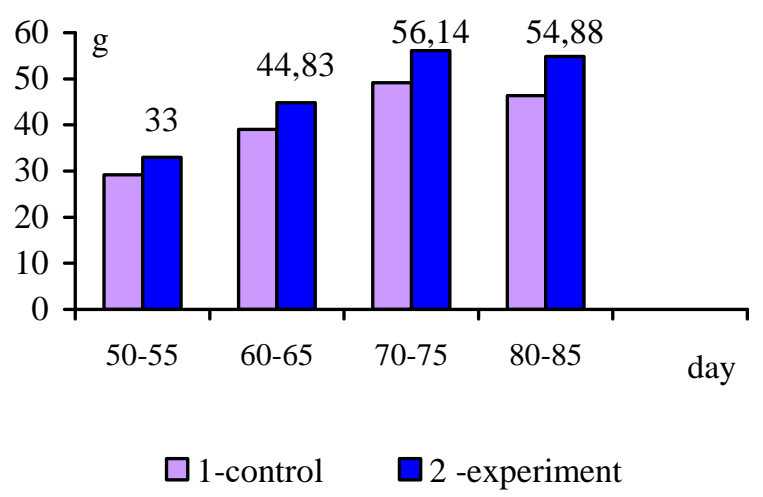

Fig. 5. Dynamics of weight gains in turkeys

Control weighing of turkeys showed that while at the beginning of the experiment the live weight in the control and experimental group was the same and was within the limits of $3.74 \pm 0.10$ and $3.77 \pm 0.08 \mathrm{~kg}$, the use of the supplement contributed to an increase in this indicator in turkeys of the 2 nd group: in 50...55 days, turkeys outperformed their peers by $4.23 \%$, in $60 \ldots 65$ days - by $6.25 \%$, in $70 \ldots 75$ days - by $7.24 \%$ and by $80 \ldots 85$ - by $9.5 \%$, respectively.

At the end of the experiment, the young birds of the 2nd group exceeded their counterparts in the 1st group by an average of $710 \mathrm{~g}$.

\section{Conclusion}

Thus, feeding a complex additive based on nanozeolite (deposits of the Ulyanovsk region) and soy okara (waste from soy production) to young turkeys improves their physiological and biochemical status and increases the intensity of metabolic processes productive qualities.

\section{References}

1. V.E. Ulitko, A.V. Kornienko, E.A. Savina, Vestnik of Ulyanovsk State Agricultural Academy, 4(44) (2018)

2. E.A. Sedova, N.A. Lubin, S.V. Dezhatkina, European Science and Technology: Materials of VII International Research and Practice Conference, April 23-24, vol. 1 (Munich, Germany, 2014)

3. I.A. Nikitina, S.V. Dezhatkina, N.V. Sharonina, Vestnik of Ulyanovsk State Agricultural Academy, 3(43) (2018)

4. S.V. Dezhatkina, N.A. Lubin, A.V. Dosorov, M.E. Dezhatkin, Research Journal of Pharmaceutical, Biological and Chemical Sciences, 5(7) (2016)

5. V.V. Akhmetova, T.M. Shlenkina, N.A. Provorova, Vestnik of Ulyanovsk State Agricultural Academy, 4(40) (2017)

6. V.E. Ulitko, S.P. Lifanova, O.E. Erisanova, Vestnik of Ulyanovsk State Agricultural Academy, 2(46) (2019)

7. A.Z. Mukhitov, S.V. Merchina, V.S. Grigoryev, Vestnik of Ulyanovsk State Agricultural Academy, 3(47) (2019)

8. E.V. Chernyshkova, V.E. Ulitko, O.A. Desyatov, Vestnik of Ulyanovsk State Agricultural Academy, 2(46) (2019)

9. V.V. Akhmetova, A.Z. Mukhitov, L.P. Pulcherovskaya, Vestnik of Ulyanovsk State Agricultural Academy, 4(44) (2018)

10. N.A. Provorova, N.V. Sharonina, A.Z. Mukhitov, Vestnik of Ulyanovsk State Agricultural Academy, 4(40) (2017)

11. N. Phenchenco, M. Malikova, J. Salmanova, Trace elements in medicine, 3(2) (2002)

12. I. Matheos-Aparisio, A. Redondo Cuensa, M. Villanueva-Suares, Food chemistry, 122(1) (2010)

13. E.M. Romanova, V.N. Lyubomirova, V.V. Romanov, M.E. Mukhitova, T.M. Shlenkina, Egyptian Journal of Aquatic Research, 4(44) (2018)

14. E.M. Romanova, V.N. Lyubomirova, V.V. Romanov, M.E. Mukhitova, T.M. Shlenkina, L.A. Shadyeva, I.S. Galushko, Journal of Fundamental and Applied Sciences, 5(10) (2018) 